\title{
Saponins are involved in the analgesic and anti-inflammatory properties of Ficus platyphylla stem bark
}

\author{
Ben A. CHINDO ${ }^{1 *}$, Joseph A. ANUKA ${ }^{2}$, Edmond ISAAC ${ }^{1}$, Augustine A. AHMADU ${ }^{3}$, \\ Florence D. TARFA ${ }^{4}$ and Karniyus S. GAMANIEL ${ }^{1}$ \\ ${ }^{1}$ Department of Pharmacology and Toxicology, National Institute for Pharmaceutical Research and \\ Development, P. M. B. 21, Abuja, Nigeria. \\ ${ }^{2}$ Department of Pharmacology and Therapeutics, Ahmadu Bello University, Zaria, Nigeria. \\ ${ }^{3}$ Department of Pharmaceutical and Medicinal Chemistry, Niger Delta University, Wilberforce Island, \\ Bayelsa State, Nigeria. \\ ${ }^{4}$ Department of Medicinal Chemistry and Quality Control, National Institute for Pharmaceutical \\ Research and Development, P. M. B. 21, Abuja, Nigeria. \\ * Corresponding author, E-mail: bachindo@yahoo.com,Tel: +2348 032899112
}

\begin{abstract}
The analgesic and anti-inflammatory properties of saponins (FPS) from the methanol extract of Ficus platyphylla stem bark were studied in rodents. FPS significantly attenuated acetic acid-induced writhes in mice and inhibited responses in both phases I \& II of formalin-induced nociception. FPS demonstrated significant antinociceptive activity in Analgesy-meter model of nociception and significantly attenuated albumin-induced oedema in rats. Morphine significantly $(\mathrm{p}<0.05)$ inhibited responses in both phases I \& II of formalin-induced nociception and increased the threshold of mechanically induced nociception in rats. The effects of FPS on formalin-induced nociception and the threshold of mechanically-induced nociception were less compare to the effects of morphine. Acetylsalicylic acid (ASA), significantly $(\mathrm{p}<0.05)$ reduced acetic acid induced writhes in mice, attenuated responses in the late phase II of formalin- induced nociception and albumin-induced oedema in rats, but failed to attenuate responses in the early phase I of the formalin-induced nociception in rats. The effects of FPS on the late phase of formalin-induced nociception were greater than the effects of ASA. Effects of FPS on acetic acid- writhes in mice were less compare to the effects of ASA. Our results provided evidence that saponins are implicated in the analgesic and anti-inflammatory effects observed in our earlier studies on the crude methanol extract of Ficus platyphylla stem bark, thus supporting the isolation and development of the saponin components of this medicinal plant as analgesics and anti-inflammatory agents.
\end{abstract}

(C) 2010 International Formulae Group. All rights reserved.

Keyword: Ficus platyphylla; saponins; anti-nociception; anti-inflammation

\section{INTRODUCTION}

The search for chemical agents to ameliorate pain and inflammation has been an effort of man throughout recorded history. Medicinal plants are known to be important sources of new chemical substances with potential therapeutic effects (Farnsworth,
1989; Eisner, 1990). Consequently, research on plants which are employed for the treatment of pain and inflammation is one of the potential and logical strategies in the search for new analgesic and antiinflammatory drugs (Elisabetsky et al., 1995). Currently available analgesics and anti- 
inflammatory drugs are often not suitable in all patients and are often accompanied by debilitating adverse effects including a high propensity for tolerance (opiates) effects, sedation and gastrointestinal effects (Vongtau et al., 2004; Burke et al., 2006; Gutstein and Akil, 2006). The development of new pharmacological agents that can overcome these barriers has become a major goal in drug research and development.

Preparations of the stem bark of Ficus platyphylla Del.-Holl (Family: Moraceae) have been used in Nigerian traditional medicine to treat psychoses, depression, epilepsy, pain and inflammation for many years and their efficacies are widely acclaimed among the Hausa communities of Northern Nigeria (Audu, 1989). The cold water extract, decoction or powder of the stem or root bark are usually taken orally while the powder is often mixed with food and eaten or placed in burning charcoal and inhaled (Audu, 1989). Our previous studies revealed that the crude methanol extract of Ficus platyphylla stem bark contains sedative principles with potential anticonvulsant, neuroleptic, analgesic and anti-inflammatory properties (Gamaniel et al., 2000; Amos et al., 2002; Chindo et al., 2003; 2009). Since saponins, which form the major components of the crude methanol extract are believed to have analgesic and anti-inflammatory properties (Gupta at al., 1969; Adzu et al., 2003., Taesotiku et al., 2003; Asongalem et al., 2004; Ojewole, 2008), we hypothesized that saponins may be involved in the analgesic and anti-inflammatory effects of the crude methanol extract earlier reported (Amos et al., 2002). Here, we evaluated the analgesic and anti-inflammatory properties of the saponin rich fraction as a step toward the isolation of biologically active components of extract of Ficus platyphylla and to complement earlier studies (Chindo et al., 2008; 2009) on this medicinal plant, which is already in common use.

\section{MATERIALS AND METHODS \\ Animals}

Swiss albino mice (18 - $25 \mathrm{~g})$ and Wistar rats (180-250 g) of either sex maintained at the Animal Facility Centre
(AFC) of the National Institute for Pharmaceutical Research and Development (NIPRD), Abuja were used. All animals were housed under standard conditions of temperature $\left(25 \pm 2{ }^{\circ} \mathrm{C}\right)$, and light approximately (12/12 h light / dark cycle) and fed on standard diet (Ladokun Feeds, Plc, Ibadan, Nigeria) and water ad libitum. These animals were approved for use by the AFC committee after reviewing the protocol for good laboratory practice and animal handling, which is in compliance with the National Institute of Health's Guide for the Care and use for Laboratory animals (Publication No. 85-23, revised 1985).

\section{Plant material}

The plant material was collected from Zaria in Kaduna State, Nigeria. The plant was identified and authenticated by Mallam I. Muazzam of the Department of Medicinal Plant Research and Traditional Medicine, National Institute for Pharmaceutical Research and Development (NIPRD), Abuja. A voucher specimen (no. 4035) was deposited at NIPRD Herbarium for future reference.

\section{Extraction of saponin components of the plant}

The method described by Ebata et al. (1996) was employed for the extraction of saponin rich fractions of Ficus platyphylla stem bark with some modifications. Briefly, $100 \mathrm{~g}$ of the coarse powder was sequentially extracted with solvents of increasing polarity including hexane, ethylacetate, dichloromethane and methanol, each for $6 \mathrm{~h}$ using a soxhlet apparatus. The resulting extracts were concentrated to dryness in vacuo at $40{ }^{\circ} \mathrm{C}$ using a rotary evaporator. The methanol extract was partitioned between water and butanol (1:3) to give butanol and aqueous fractions. The butanol fraction was then dissolved in methanol and added dropwise to diethylether. A precipitate was formed, which was separated from the solution by filtration to give the saponin rich fraction designated FPS. The FPS was used for analgesic and anti-inflammatory studies. 


\section{Formalin test}

The method used for this test was similar to that described by Dubuisson and Dennis (1977) and modified by Vongtau et al. (2004). Adult wistar rats were divided into six groups of six rats each and pre-treated p.o. as follows: group I received normal saline as control; groups II, III and IV received FPS at doses of 25,50 and $100 \mathrm{mg} / \mathrm{kg}$, p.o. respectively, while groups $\mathrm{V}$ and $\mathrm{VI}$ received acetylsalicylic acid (150 mg/kg, p.o.) and morphine $(4 \mathrm{mg} / \mathrm{kg}$, s.c.) respectively. Thirty minute after these treatments the rats were administered $50 \mu \mathrm{l}$ of a $2.5 \%$ solution of formalin subcutaneously under the plantar surface of the left hind-paw. They were then placed in an observation chamber in such a way as to ensure an un-obstructed view of the injected paw and monitored for $1 \mathrm{~h}$. Severity of pain responses were recorded based on the following scale: (0) rats walked or stood firmly on injected paw; (1) the injected paw was favored or partially elevated; (2) the injected paw was clearly lifted off the floor; (3) the rat licked, chewed or shook the injected paw. Anti-nociceptive effect was determined in two phases, the early phase (I) being recorded during the first 5 min while the late phase (II) was recorded during the last 45 min with a $10 \mathrm{~min}$ lag period in between the two phases.

\section{Acetic acid test}

The method described by Koster et al. (1959) was used with some modifications. The mice were randomly-divided into five test groups of six mice each. The first three groups were pre-treated with 25,50 and $100 \mathrm{mg} / \mathrm{kg}$, p.o. of FPS, respectively. Two other groups received normal saline $3 \mathrm{ml} / \mathrm{kg}$ and acetyl salicylic acid $150 \mathrm{mg} / \mathrm{kg}$ orally (p.o.), respectively, to serve as controls. Thirty minutes after pre-treatment, each mouse was injected with $10 \mathrm{ml} / \mathrm{kg}$ of an aqueous solution of $0.7 \%$ acetic acid i.p. and placed in a transparent Perspex observation box. After a five minute lag period, the number of writhes (a syndrome characterized by a wave of contraction of the abdominal musculature followed by extension of hind limbs) for each mouse was counted for five minutes at 30 and 60th min respectively.

\section{Pain threshold test}

The study involved the use of Analgesymeter (Model 7200, Ugo Basile, Italy) as described by Vongtau et al. (2004). The force is monitored by a pointer moving along a linear scale and the rat's response is taken to be the point at which it struggles or its paw slips off the plinth of the instrument. Rats were divided into five groups of six rats each and pre-treated as follows: Groups I, II and III received FPS at doses of 25, 50 and $100 \mathrm{mg} / \mathrm{kg}$ p.o., respectively, while groups IV and $\mathrm{V}$ received normal saline and morphine (4 $\mathrm{mg} / \mathrm{kg}$, s.c.) respectively. Thirty minutes after treatment, readings were taken at thirty minutes intervals for $120 \mathrm{~min}$.

\section{Anti-inflammatory test}

This test was carried out using a modification of Winter et al. (1963) as described by Akah and Nwambie (1994). The rats were divided into five groups of six rats of either sex and pre-treated as follows: Group I (control) received normal saline $(3 \mathrm{ml} / \mathrm{kg}$ p.o.), groups II, III and IV received 25, 50 and $100 \mathrm{mg} / \mathrm{kg}$ of FPS p.o., respectively, while group $\mathrm{V}$ received acetyl salicylic acid (150 $\mathrm{mg} / \mathrm{kg}$, p.o.). After $30 \mathrm{~min}$ of post-drug administration, rats in each group were injected with $50 \mu 1 / \mathrm{kg}$ raw egg albumin in the sub-plantar surface of the left hind-paw thereby inducing pedal oedema. A digital plethysmometer (Letica, Spain LE7500) was used to measure the volume of paw oedema (volume displacement) for a period of 120 minutes, with readings taken at $20 \mathrm{~min}$ intervals, i.e. 20, 40, 60, 80, 100 and $120 \mathrm{~min}$ after albumin administration.

\section{Statistical analysis}

Data were expressed as mean \pm S.E.M with $n$ indicating the number of replicates for a given experiment. Data were analyzed by one-way ANOVA followed by Dunnet's post 
hoc test for multiple comparisons. Results were considered significant at $p<0.05$

\section{RESULTS}

The oral $\mathrm{LD}_{50}$ of FPS and the crude methanol extract, from which FPS was obtained, were reported earlier to be $1274 \pm$ $42.2 \mathrm{mg} / \mathrm{kg}$ and $>5000 \mathrm{mg} / \mathrm{kg}$ respectively (Amos et al., 2002; Chindo et al., 2009). At higher doses, FPS caused a dose related decrease in locomotor activity, sedation and drowsiness (hypnosis), respiratory distress and subsequently death of the animals (Chindo et al., 2009).

FPS at doses of 25, 50 and $100 \mathrm{mg} / \mathrm{kg}$ showed dose-dependent anti-nociceptive activities in all the three experimental models of nociception studied. There was a significant $(\mathrm{p}<0.05)$ reduction in responses to formalininduced pain in rats in both phases I and II by FPS $(25,50,100 \mathrm{mg} / \mathrm{kg})$. Morphine $(4 \mathrm{mg} / \mathrm{kg})$ significantly $(\mathrm{P}<0.05)$ attenuated the responses to formalin-induced pain in the 2 phases compared to control, while ASA at 150 $\mathrm{mg} / \mathrm{kg}$, showed higher activity in the late phase (phase II). FPS (25, 50, $100 \mathrm{mg} / \mathrm{kg}$ ) significantly $(\mathrm{p}<0.05)$ attenuated the number of acetic acid-induced writhes in mice. Acetylsalicylic acid significantly $(\mathrm{p}<0.05)$ inhibited acetic acid-induced writhes in mice. The percentile inhibition of early phase of formalin-induced nociception by FPS $(25,50$, $100 \mathrm{mg} / \mathrm{kg}$ ), aspirin and morphine are $35.7 \%$, $50 \%, 64.3 \%, 14.3 \%$ and $71.4 \%$ respectively; In the late phase of formalin-induced nociception, the percentile inhibition observed following the administration of FPS $(25,50$, $100 \mathrm{mg} / \mathrm{kg}$ ), aspirin and morphine are $69.2 \%$, $76.9 \%, 53.8 \%, 53.8 \%$ and $61.5 \%$. The inhibition of acetic acid-induced writhes by FPS $(25,50,100 \mathrm{mg} / \mathrm{kg})$ and aspirin are $66.1 \% .73 .8 \%, 86.9 \%$ and $76.8 \%$ respectively at the $30 \mathrm{~min}$ after administration of test extract and aspirin; and 67.2\%, 76.7\%, 89.7\% and $89 \%$ respectively after $60 \mathrm{~min}$ of test extract and aspirin administration.

In analgesymeter model that employ mechanically induced pain, FPS significantly $(\mathrm{p}<0.05)$ demonstrated antinociceptive activity in rats. Morphine expectedly exhibited a significant $\quad(\mathrm{p}<0.05)$ antinociceptive effect in the analgesymeter model as well. FPS significantly inhibited albumin-induced oedema in rats over a period of $120 \mathrm{~min}$ duration. Effects were dosedependent and comparable to the standard anti-inflammatory drug (ASA) used in this study.

\section{DISCUSSION}

The data presented in this study provide scientific evidence that saponins (FPS) obtained from crude methanol extract of Ficus platyphylla stem bark may contain biologically active principles that are relevant in the management of pain and inflammation. FPS showed significant and dose dependent antinociceptive activity against formalin, acetic acid and analgesy-meter models of pain, suggesting the presence of both central and peripheral pathway modulatory activities. In the formalin test there is a distinctive biphasic nociceptive response termed early and late phases. The early phase, which starts immediately after formalin injection and continues for $5 \mathrm{~min}$, reflects centrally mediated pain while the late phase that begins 15 - $20 \mathrm{~min}$ after formalin injection and continue for approximately to $60 \mathrm{~min}$ duration, is due to inflammation with a release of serotonin, histamine, bradykinin and prostaglandins (Tjolsen et al., 1992) and at least to some degree, the sensitization of central nociceptive neurons (Coderre et al., 1990; Coderre and Melzack, 1992; Tjolsen et al., 1992). Consequently, centrally acting drugs such as opiates inhibit both early and late phases (Vogel and Vogel, 1997), whereas non-narcotic analgesics such as acetyl salicylic acid, hydrocortisone, and dexamethasone, which are primarily peripherally acting, only inhibit the late phase (Chen et al., 1995; Elisabetsky et al., 1995; Santos et al., 1995). Suppression of both phases of nociception by FPS in this study suggests the presence of both central and 


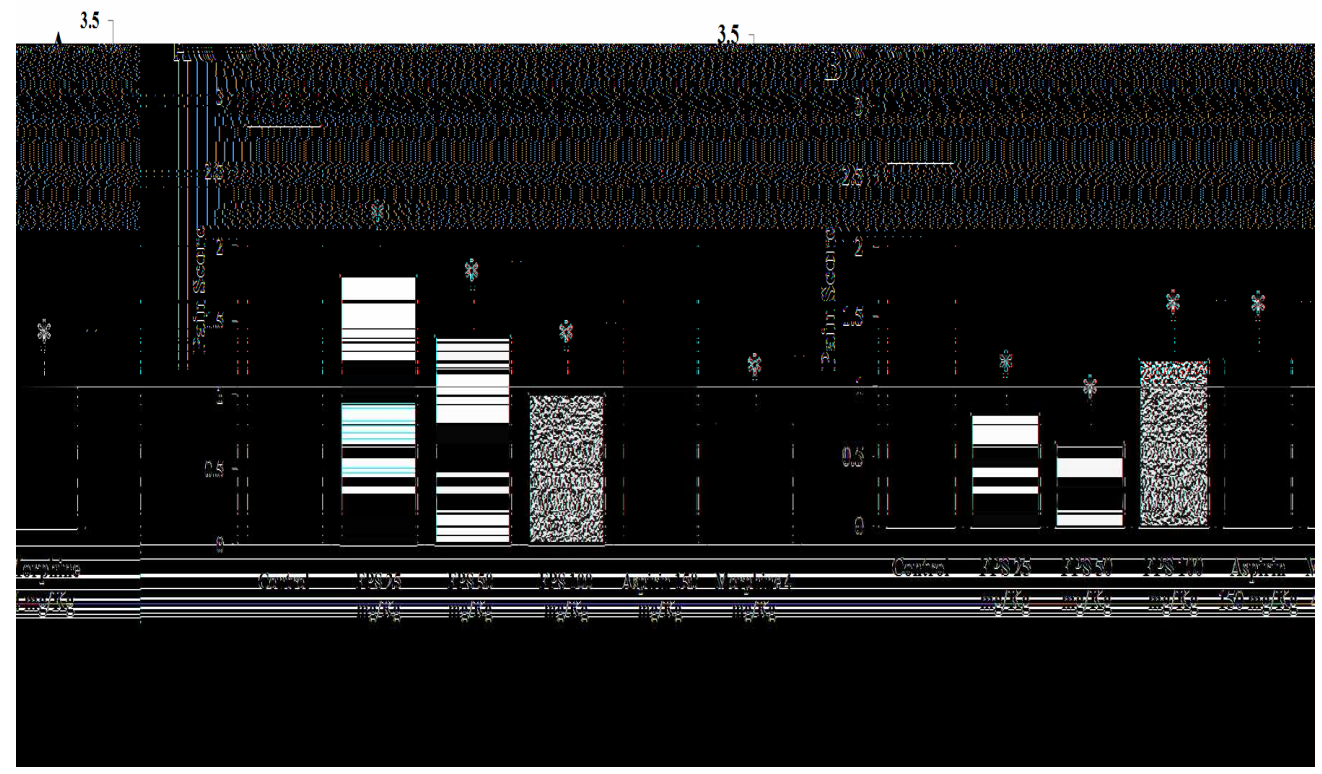

Figure 1: Effect of FPS on the early phase of formalin-induced pain in rats. (A) Pain score of the early phase of formalin-induced nociception and (B) Pain score of the late phase of formalin-induced nociception in rats. *significantly different from control $(\mathrm{p}<0.05, \mathrm{n}=6)$.

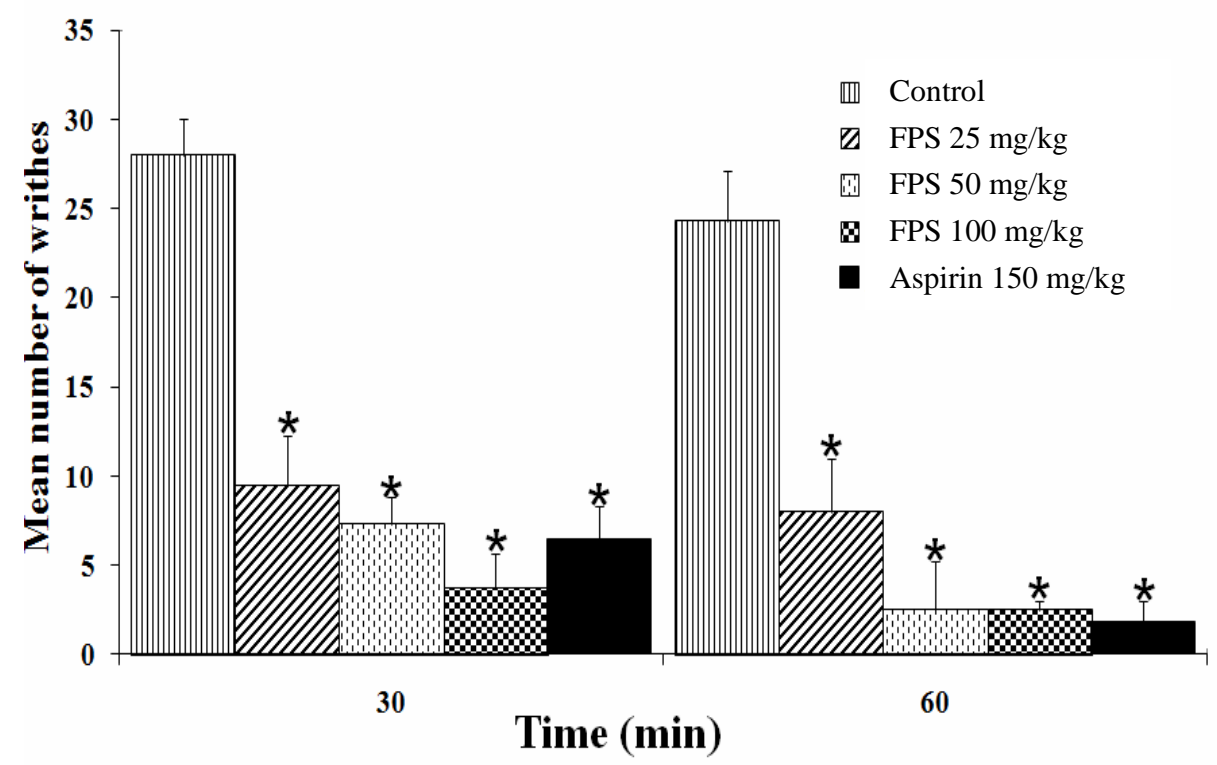

Figure 2: Effects of FPS on acetic acid-induced writhes in mice. (A) Figures represent Mean number writhes \pm SEM. $*$ significantly different from control $(\mathrm{p}<0.05, \mathrm{n}=6)$. 


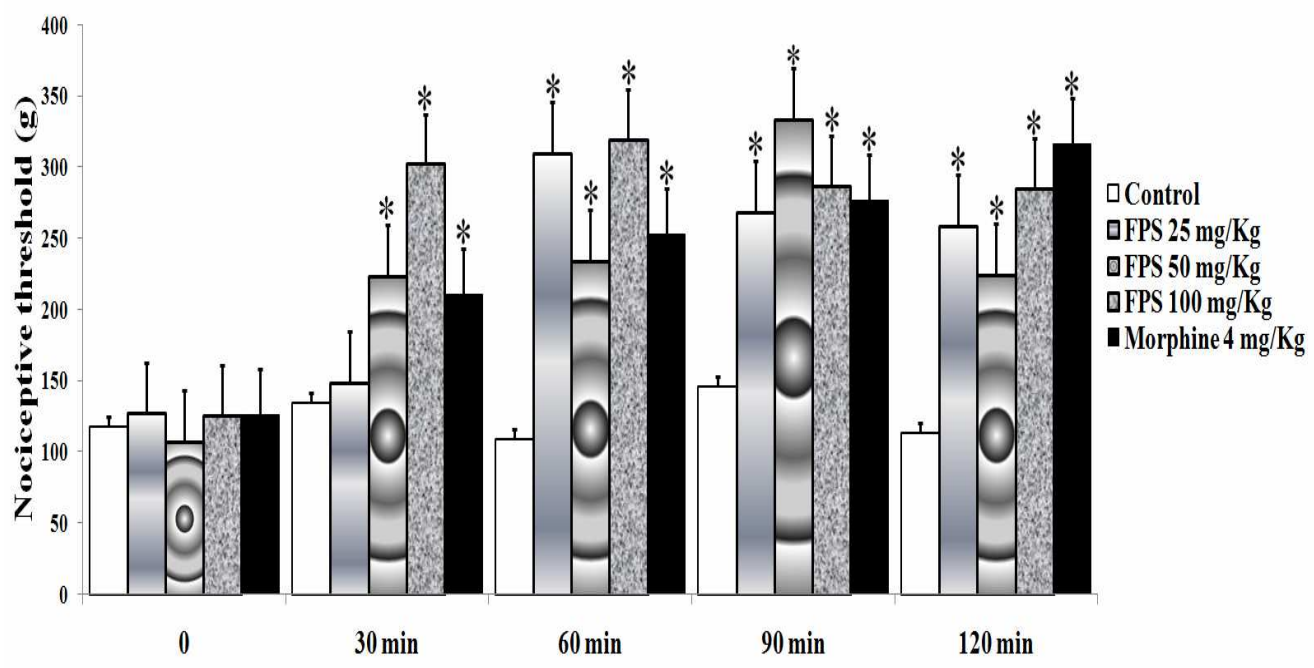

Figure 3: Effects of FPS on pain threshold in analgesy-meter tests in rats. *significantly different from control $(\mathrm{p}<0.05, \mathrm{n}=6)$.

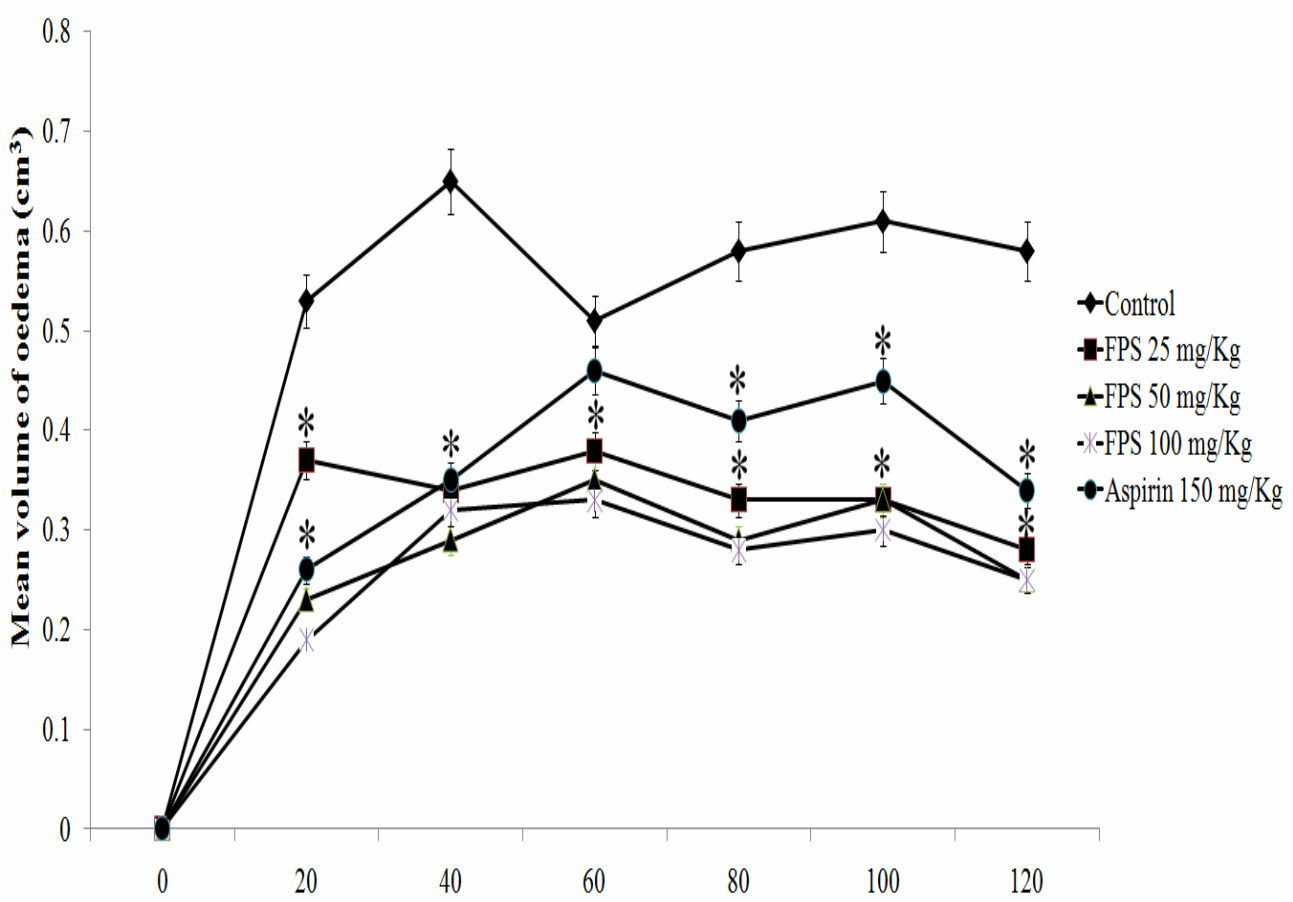

Figure 4: Anti-inflammatory effects of FPS in rats.

* significantly different from control $(\mathrm{p}<0.05, \mathrm{n}=6)$. 
peripheral activities (Chan, et al., 2000; Tjolson et al., 1992).

FPS significantly attenuated acetic acid induced pain in mice dose-dependently, which is consistent with previous findings on the crude methanol extracts (Amos et al., 2002). The abdominal constriction response induced by acetic acid is a sensitive procedure to evaluate peripherally acting analgesics (Gene et al., 1998). This model is able to detect antinociceptive activities of compounds at dose levels that may appear inactive in other models of pain (Collier et al., 1968; Bentley et al., 1981). Local peritoneal receptors, increased levels of prostaglandins, bradykinins, serotonin, substance $\mathrm{P}$ and leukotrienes in peritoneal fluids are postulated to be partly involved in the acetic acidinduced abdominal constriction response (Bentley et al., 1983; Levini et al., 1984; Dhara et al., 2000). The significant reduction in acetic acid-induced writhes by FPS suggests that the analgesic effect may be peripherally mediated via the inhibition of synthesis and release of prostaglandins and other related endogenous substances.

The analgesy-meter antinociceptive test is useful in elucidating centrally mediated antinociceptive responses, which focuses mainly on changes above the spinal cord level (Vongtau et al., 2004). The significant increase in pain threshold produced by FPS in the analgesymeter test suggests involvement of central pain pathways. Pain is centrally modulated via a number of complex processes including opiate, dopaminergic, descending noradrenergic and serotonergic systems (Bensreti and Sewel, 1983; Headley and Oshaughnessy, 1985; Wigdor and Wilcox, 1987; Pasero et al., 1999; Salawu et al., 2008). The analgesic effect produced by this extract therefore may be via central mechanisms involving opiate, dopaminergic, descending noradrenergic and serotonergic systems or via peripheral mechanisms involved in the inhibition of prostaglandins, leucotrienes, and other endogenous substances that are key players in inflammation and pain.
The results of the anti-inflammatory studies suggest that FPS possess antiinflammatory principles of high potency. There are several mechanisms involved in the anti-inflammatory activity of drugs. They include the endogenous release of glucocorticoids, interaction with prostaglandin biosynthesis, interaction with tachykinins or other inflammatory mediators (Barnes et al., 1990; Vongtau et al., 2004). It is difficult to ascertain from this data, the exact mechanism by which FPS achieved anti-inflammatory activity. However, the anti-inflammatory effects are comparable to those of nonsteroidal anti-inflammatory drugs, particularly the salicylates and their derivatives.

In conclusion, we have presented scientific evidence that saponins are involved in the analgesic and anti-inflammatory effects earlier observed in our studies (Amos et al., 2002) on the methanol extract of Ficus platyphylla stem bark, thus supporting the isolation and development of the saponin components of this medicinal plant as analgesic and anti-inflammatory agents.

\section{ACKNOWLEDGEMENTS}

This work was funded by a research grant from the National Institute for Pharmaceutical Research and Development (NIPRD), Abuja, Nigeria. The authors are grateful to Sunday Dzarma and Hauwa Abdullahi for their technical assistance and Charles Balogun for secretarial assistance.

\section{REFERENCES}

Adzu B, Amos S, Kapu SD, Gamaniel KS. 2003. Anti-inflammatory and antinociceptive effects of Shaeranthus senegalensis. J. Ethnopharmacol., 84: 169-173.

Akah PA, Nwambie AI. 1994. Evaluation of Nigerian traditional medicines: plants used for rheumatic disorders. $J$. Ethnopharmacol., 42: 179-182.

Amos S, Chindo B, Edmond I, Akah P, Wambebe C, Gamaniel K. 2002. Antiinflammatory and anti-nociceptive effects of Ficus platyphylla in rats and 
mice. J. Herbs, Spices and Med Pl., 9: $47-53$.

Asongalem EA, Foyer HS, Ngogang J, Folefoc GN, Dimo T, Kamtchouing P. 2004. Analgesic and anti-inflammatory activities of Erigeron Floribundus. $J$. Ethnopharmacol., 91: 301-308.

Audu JA. 1989. Medicinal plants and their use in Bauchi State. Nig. Field, 54: 157-168.

Barnes PJ, Belivisi MG, Rogers DF. 1990. Modulation of neurogenic inflammation: Novel approaches to inflammatory disease. Tr. Pharmacol. Sci., 11: 185189

Bensreti MM, Sewell RDE. 1983. Selective effects of dopaminergic modifiers on antinociception produced by different opioid receptoragonists. Pro. Br. Pharmacol. Soc. 6th - 8th July, pp. 70.

Bentley GA, Newton SH, Starr J. 1981. Evidence for an action of morphine and the enkephalins on sensory nerve endings in the mouse peritoneum. $\mathrm{Br} . \mathrm{J}$. Pharmacol., 73: 325-332.

Bentley GA, Newton SH, Starr J. 1983. Studies on the antinociceptive action of á-agonist drugs and their interaction with opioid mechanisms. Br. J. Pharmacol., 79: $125-134$.

Burke A, Smyth EM, Fitzgerald GA. 2006. Analgesic-Antipyretic and antinflammatory agents; pharmacotherapy of gout. In Goodman \& Gilman's The Pharmacological basis of Therapeutics, Brunton LL, Lazo JS, Parker KL, (eds). McGraw-Hill Co.Inc.: New York; 671 715.

Chan K, Islam MW, Kamil M, Radhakrishna R, Zakaria MNM, Habibullah M, Attas A. 2000. The analgesic and antiinflammatory effects of Portulaca oleracea L. subsp. sativa (Haw.) Celak. J. Ethnopharmacol., 73: 445-451.

Chen YF, Tsai HY, Wu TS. 1995. Antiinflammatory and analgesic activity from roots of Angelica pubescens. Planta Med., 61: 2-8.

Chindo BA, Amos S, Odutola AA, Vongtau HO, Abbah J, Wambebe C, Gamaniel
KS. 2003. Central nervous system activity of the methanol extract of Ficus platyphylla stem bark. J. Ethnopharmacol., 85: 131-137.

Chindo BA, Anuka JA, Lees G, Yaro AH, Adamu SS, Amos S, Wambebe C, Gamaniel KS (2008): Psychopharmacological properties of the saponin fraction of Ficus platyphylla stem bark. Int. J. Biol. Chem. Sci., 2: 239-248.

Chindo BA, Anuka JA, McNeil L, Yaro AH, Adamu SS, Amos S, Connelly WK, Lees G, Gamaniel KS. 2009. Anticonvulsant properties of saponins from Ficus platyphylla stem bark. Br. Res. Bull. 78: 276-282.

Coderre TJ, Melzack R. 1992. The contribution of excitatory amino acids to central sensitization and persistent nociception after formalin-induced tissue. J. Neurosci., 12: 3665-3670.

Coderre TJ, Vacarino AL, Melzack R. 1990. Central nervous system plasticity in the tonic pain response to subcutaneous formalin injection. Br. Res., 535: $155-$ 158.

Collier HOJ, Dinneen LC, Johnson CA, Schneider C. 1968. The abdominal constriction response and its suppression by analgesic drugs in the mouse. $B r . J$. Pharmacol., 32: 295-310.

Dhara AK, Suba V, Sen T, Pal S, Nag Chaudhuri AK. 2000. Preliminary studies on the anti-inflammatory and analgesic activity of the methanolic fraction of the root extract of Tragia involucrate. J. Ethnopharmacol., 72 : 265-268.

Dubuisson D, Dennis SG. 1977. The formalin test: a quantitative study of the analgesic effect of morphine, meperidine, and brain stem stimulation in rats and cats. Pain, 4: 161-174.

Ebata N, Nakajima K, Hayashi K, Okada M, Maruno M. 1996. Saponins from the root of Bupleurum falcatum. Phytochem., 41: 895-901.

Eisner T. 1990. Chemical prospecting. A call for action. In Ecology, Economic and 
Ethics: The Broken Circle, Borman FH, Kellert SR (eds). Yale University Press.

Elisabetsky E, Ahmador TA, Albuquerque RR, Nunes DS, Caravalho ACT. 1995. Analgesic activity of Pyschotria colorata (Wild. ex-R. and S.) Muell. Arg. alkaloids. J. Ethnopharmacol., 48: 77-83.

Farnsworth NR, (1989): Screening plants for new medicines. In Biodiversity, Part II, Wilson EO (ed). National Academy Press: Washington; 83-97.

Gamaniel K, Amos S, Chindo B, Wambebe C, Vongtau H, Olusola A, Abdulrahman EM, Odutola AA, Akah PA, Adamu SS. 2000. Behavioural effects of the methanolic extract of Ficus platyphylla bark in mice and rats. Nig. J. Neurosci., 3: $17-23$.

Gené RM, Segura L, Adzet T, Marin E, Inglesias J. 1998. Heterotheca inuloides: anti-inflammatory and analgesic effects. J. Ethnopharmacol., 60: 157-162.

Gupta MB, Bhalla TN, Gupta GP, Mitra CR, Bhargava KV. 1969. Anti-inflammatory activity of natural products: 1: Triterpenoids. Eur. J. Pharmacol., 32: 191-196.

Gutstein HB, Akil H. 2006. Opioid analgesics. In Goodman \& Gilman's The Pharmacological basis of Therapeutics, Brunton LL, Lazo JS, Parker KL (eds). McGraw-Hill Co. Inc: New York; 547590.

Headley PM, O'Shaughnessy CT. 1985. Evidence for opiate and dopamine interaction in striatum. Br. J. Pharmacol., 86 (pro. Suppl.): 700.

Koster R, Anderson M, De Boer EJ. 1959. Acetic Acid for Analgesic Screening. Fed. Pro., 18: 412.

Levini JD, Lau W, Kwait G, Goetzl EJ. 1984. Leukotriene B4 produces hyperalgesia that is dependent on the polymorphonuclear leucocytes. Science 225: 743-745.
Ojewole JAO. 2008. Analgesic and antiinflammatory effects of mollic glucoside, a 1 $\alpha$-hydroxycycloartenoid saponin extractive from Combretum molle R.Br. ex G Don (combretaceae) leaf. Phytother. Res., 22: 30-35.

Pasero C, Paice JA, McCaffery M. 1999. Basic Mechanisms underlying the causes and effects of pain. In Pain, McCaffery M, Pasero C (eds). Mosby: St. Louis; 1534.

Salawu OA, Chindo BA, Tijani AY Adzu B. 2008. Analgesic, anti-inflammatory, antipyretic and antiplasmodial effects of the methanolic extract of Crossopteryx febrifuga. J. Med Plants Res., 2(8): 213218.

Taesotiku T, Panthong A, Kanjanapothi D, Verporte R, Scheffer JJC. 2003. Antiinflammatory, antipyretic and antinociceptive activities of Tabernaemontana pandacaqui Poir. J. Ethnopharmacol., 84: $31-35$.

Tjolsen A, Berge OG, Hunskaar S, Rosland JH, Hole K. 1992. The formalin test: an evaluation of the method. Pain, 51: 517.

Vogel HG, Vogel WH. 1997. Drug Discovery and Evaluation: Pharmacological Assays. Springer-Verlaag: Berlin, Heidelberg.

Vongtau HO, Abbah J, Mosugu O, Chindo BA, Ngazal IE, Salawu AO, Kwanashie HO, Gamaniel KS. 2004. Antinociceptive profile of the methanolic extract of Neorautanenia mitis root in rats and mice. $J$. Ethnopharmacol., 92(2 \& 3): 317-324.

Wigdor S, Wilcox GL. 1987. Central and systemic morphine-induced antinociception in mice: Contribution of descending serotonergic and noradrenergic pathways. J. Pharmacol. Exp. Ther., 242: 90-95.

Winter EA, Risley EA, Nuss GV. 1963. Antiinflammatory and antipyretic activities of indomethacin. J. Pharmacol. Exp. Ther., 141: 369-376. 